\title{
Long-Term Remissions in Metastatic Malignant Melanoma Following Chemotherapy and Tamoxifen Maintenance
}

\author{
Bernd Metzner $^{\mathrm{a}} \quad$ Jochen Casper $^{\mathrm{a}} \quad$ Gernot Hartung $^{\mathrm{a}} \quad$ Bernd Rosien $^{\mathrm{a}}$ \\ Erhard Hölzle $^{\mathrm{b}}$ Peter Pelzer ${ }^{\mathrm{b}}$ Claus-Henning Köhne ${ }^{\mathrm{a}}$ \\ ${ }^{a}$ Klinik für Onkologie und Hämatologie, \\ ${ }^{\mathrm{b}} \mathrm{Klinik}$ für Dermatologie and Allergologie, Klinikum Oldenburg, Germany
}

\section{Keywords}

Melanoma - Maintenance therapy - Metastatic disease . Long-term follow-up - Tamoxifen

Malignant melanoma with distant metastases is regarded as an incurable disease with a short median survival time $(<6$ to 12 months). Only a few long-term remissions after chemotherapy lasting 10 or more years have been reported [1]. In a retrospective evaluation, we observed 6 patients who developed a continuous remission following chemotherapy and tamoxifen maintenance therapy (20 $\mathrm{mg}$ orally per day for up to 10 years). The remission duration varied from 1 to 16 years (median 8.6 years).

In the last 17 years, we treated in our institution 23 patients with distant metastases with first-line chemotherapy (dacarbazine (DTIC) or bis-chloronitrosourea (BCNU)/cisplatin/ DTIC/tamoxifen (BCDT)) outside of a clinical trial. The primary diagnoses were cutaneous malignant melanomas; only 1 patient (no. 5 in the table) had a malignant melanoma of the anus.

12 out of 23 patients reached a partial remission or stable disease and were afterwards treated with tamoxifen $20 \mathrm{mg}$ per day after giving informed consent (table 1). 6 out of these 12 patients developed a continuous remission as mentioned above, 4 of these showed a complete remission, and 2 patients had a continuous partial remission lasting for 62 and 13 months, respectively. No relevant side effects were observed. The patients were seen regularly for a follow-up every 3-6 months. The examination included a chest radiograph, abdominal ultrasonography, blood tests including the serum tumor marker S100 and, from time to time, a computed tomography (CT) scan or magnetic resonance (MR) tomography.

As shown in table 1, no obvious prognostic factors can be detected, probably due to the small number of patients.
It is remarkable that patients 1 and 2 developed progressive disease under tamoxifen maintenance (after 17 and 7 months, respectively), but remained in complete remission following local therapy (exstirpation of a kidney metastasis and an adrenal body in patient 1 ; irradiation of the lumbar spine, the sacrum and the right humerus in patient 2) and continuation of tamoxifen therapy.

Four out of these 6 patients had liver metastases, usually indicating a particularly poor prognosis. 2 of them (patients 1 and 2) have shown a continuous complete remission for 16 and 13 years, respectively. Up to now, to our knowledge, there has been only 1 case published with a continuous complete remission of liver metastases for 10 years (following vindesine and interferon) [1].

As potential action mechanisms of tamoxifen in malignant melanoma, induction of apoptosis and inhibition of angiogenesis [2], inactivation of the insulin-like growth factor-1 receptor [3], or inhibition of tumor cell invasion and metastasis through suppression of the PKC/MEK/ERK and PKC/PI3K/ Akt pathways [4] have been discussed. Tamoxifen monotherapy in metastatic melanoma has been reported to induce remissions in about $5 \%$ of the patients, in some cases after progression of the disease in the first months of therapy [5]. In combination with chemotherapy, tamoxifen failed to exert an additional therapeutic effect in most studies [6]. But, to our knowledge, no results are published about tamoxifen maintenance following chemotherapy.

Given the good tolerability and low costs of the drug, it would be worthwhile to start a clinical trial with a larger number of patients to investigate the potential of tamoxifen maintenance in metastatic malignant melanoma, if possible.

\section{Disclosure Statement}

The authors declare no conflict of interest.

\section{KARGER \\ Fax +497614520714 \\ Information@Karger.de}

www.karger.com (c) 2011 S. Karger GmbH, Freibur

0378-584X/11/0344-0208\$38.00/0

Accessible online at:

www.karger.com/onk
Dr. Bernd Metzner

Klinik für Onkologie und Hämatologie

Klinikum Oldenburg

Rahel-Straus-Str. 10, 26133 Oldenburg, Germany

Tel. +49 441 403-2611, Fax -2654

metzner.bernd@klinikum-oldenburg.de 
Table 1. Patient characteristics

\begin{tabular}{|c|c|c|c|c|c|c|c|c|c|}
\hline No. & Sex & $\begin{array}{l}\text { Age }^{\mathrm{a}} \\
\text { years }\end{array}$ & $\begin{array}{l}\text { Time to distant } \\
\text { metastases }^{\mathrm{b}} \text {, } \\
\text { months }\end{array}$ & $\begin{array}{l}\text { Metastatic } \\
\text { manifestations }\end{array}$ & $\begin{array}{l}\text { PS } \\
(\mathrm{ECOG})^{\mathrm{c}}\end{array}$ & $\begin{array}{l}\mathrm{LDH}^{\mathrm{d}}, \\
\mathrm{U} / 1\end{array}$ & Pretreatment & $\begin{array}{l}\text { Chemotherapy } \\
\text { and result }\end{array}$ & $\begin{array}{l}\text { Remission } \\
\text { duration, } \\
\text { months }\end{array}$ \\
\hline 1 & $\mathrm{~m}$ & 73 & 23 & liver, skin & 0 & 292 & none & BCDT $3 \times:$ NC & $190+$ \\
\hline 2 & $\mathrm{~m}$ & 50 & 0 & $\begin{array}{l}\text { liver, spleen, lung, } \\
\text { bone, nodes }\end{array}$ & 2 & normal & none & $\begin{array}{l}\text { BCDT } 1 x^{\mathrm{f}}, \text { vindesin, } \\
\text { CPL/DTIC: PR }\end{array}$ & $156+$ \\
\hline 3 & $\mathrm{f}$ & 65 & 81 & $\begin{array}{l}\text { vena cava tumor } \\
\text { thrombus, (adrenal } \\
\text { body exstirpated) }\end{array}$ & 1 & normal & none & DTIC $6 \times:$ PR & $142+$ \\
\hline 4 & $\mathrm{~m}$ & 61 & 23 & liver, lung & 1 & normal & IFN & BCDT $4 \times:$ PR & $65+$ \\
\hline 5 & $\mathrm{f}$ & 63 & 3 & liver, lung, nodes & 1 & 319 & none & BCDT $4 \times:$ PR & $27+$ \\
\hline 6 & $\mathrm{~m}$ & 69 & 30 & lung, skin, nodes & 2 & normal & none & DTIC $6 \times:$ PR & $13+$ \\
\hline 7 & $\mathrm{f}$ & 63 & 24 & lung, skin & 1 & normal & none & BCDT $2 \times:$ PR & 18 \\
\hline 8 & $\mathrm{f}$ & 55 & 10 & lung, nodes & 0 & normal & IFN & BCDT $4 \times$ : NC & 7 \\
\hline 9 & $\mathrm{f}$ & 57 & 7 & $\begin{array}{l}\text { nodes }+ \text { M. psoas, } \\
\text { bone }\end{array}$ & 1 & 327 & IFN & BCDT $3 \times: \mathrm{NC}$ & 6 \\
\hline 10 & $\mathrm{f}$ & 63 & 56 & lung, spleen, nodes & 0 & normal & none & BCDT $4 \times:$ PR & 2 \\
\hline 11 & $\mathrm{~m}$ & 52 & 21 & jejunum & 0 & normal & IFN, RT & $\begin{array}{l}\text { DTIC/Carbo } 2 \times, \\
\text { BCDT } 1 \times, \\
\text { DTIC } 1 \times: \text { NC }\end{array}$ & 2 \\
\hline 12 & $\mathrm{~m}$ & 51 & 55 & liver, bone & 2 & 357 & None & BCDT $4 \times:$ PR & 1 \\
\hline
\end{tabular}

${ }^{\mathrm{a}}$ Age at relapse.

${ }^{\mathrm{b}}$ Time from diagnosis of the primary tumor to first distant metastasis.

'Performance status (Eastern Cooperative Oncology Group) at relapse.

${ }^{\mathrm{d}} \mathrm{LDH}$ at relapse (normal up to $\left.240 \mathrm{U} / \mathrm{l}\right)$.

${ }^{\mathrm{e}} \mathrm{Lymph}$ nodes.

${ }^{\mathrm{f}}$ BCDT $1 \times$ means 3 weeks of treatment.

LDH: Lactate dehydrogenase; BCDT: BCNU/cisplatin/dacarbacine/tamoxifen; IFN: interferon- $\alpha$; RT: radiotherapy; CPL: cisplatin; DTIC: dacarbazine; Carbo: carboplatin; NC: no change; PR: partial remission.

\section{References}

1 Iqbal M, Marshall E, Green JA: Ten-year survival in advanced malignant melanoma following treatment with interferon and vindesine. Ann Oncol 2000;11:483-485.

2 Toma S, Ugolini D, Palumbo R: Tamoxifen in the treatment of metastatic malignant melanoma: still a controversy? Int J Oncol 1999;15:321-337.
Kanter-Lewensohn L, Gimita L, Gimita A, Dricu A, Olsson G, Leech L, Nilsson G, Hilding A, Wejde J, Brismar K, Larsson O: Tamoxifen-induced cell death in malignant melanoma cells: possible involvement of the insulin-like growth factor-1 (IGF-1) pathway. Mol Cell Endocrinol 2000;165:131-137.

-4 Matsuoka H, Tsubaki M, Yamazoe Y, Ogaki M, Satou T, Itoh H, Kusunoki T, Nishida S: Tamoxifen inhibits tumor cell invasion and metastasis in mouse melanoma through suppression of $\mathrm{PKC} /$ MEK/ERK and PKC/PI3K/Akt pathways. Exp Cell Res 2009;315:2022-2032.
Amin R: Complete regression of pulmonary metastases from malignant melanoma of the vulva following therapy with tamoxifen. Br J Radiol 1986;59:171-173.

6 Beguerie JR, Xingzhong J, Valdez RP: Tamoxifen vs. non-tamoxifen treatment for advanced melanoma: a meta-analysis. Int J Dermatol 2010; 49:1194-1202. 